DOI 10.4467/2543733XSSB.21.017.13810

KRZYSZTOF NOWAK

Uniwersytet Śląski w Katowicach

\title{
DYPLOMACJA NICOLAE CEAUŞESCU WOBEC PRZEMIAN POLITYCZNYCH W POLSCE W 1989 ROKU
}

\section{Nicolae Ceauşescu's Diplomacy in the Face of Political Changes in Poland in 1989}

\author{
Summary
}

In 1989, Romania belonged to the communist countries, which particularly strongly attacked communist Poland for carrying out democratic reforms. For many months the diplomacy of communist leader Nicolae Ceaşescu tried to organize a conference of socialist countries on the subject of Poland, but as a result of Moscow's opposition it did not come to fruition. During the Gorbachev era, the Soviet Union rejected the Brezhnev doctrine, while Romania actually urged its restoration. This was in contradiction with the current political line of Ceauşescu in favor of not interfering in the internal affairs of socialist countries. However, in 1989 it was a threat to communism, which is why historians also have polemics about Romanian suggestions for the armed intervention of the Warsaw Pact in Poland. In turn, Romania did not allow Poland to interfere in the problems of the Polish minority in Bukovina.

Key words: Nicolae Ceauşescu, Romania in 1989, Romanian-Polish relations in 1989, communist states in 1989

Słowa kluczowe: Nicolae Ceauşescu, Rumunia w 1989, stosunki rumuńsko-polskie w 1989, państwa komunistyczne w 1989

$\mathrm{Na}$ tle innych satelitów Kremla poczynania dyplomacji Socjalistycznej Republiki Rumunii od połowy lat 60. XX wieku, czyli w okresie objęcia władzy nad Rumuńską Partią Komunistyczną przez Nicolae Ceauescu, kojarzyły się z publicznym demonstrowaniem pewnej niezależności od Moskwy, podkreślaniem suwerenności, wzajemnej nieingerencji W wewnętrzne sprawy państw Bloku Wschodniego, czy własnej drogi do komunizmu. Najbardziej spektakularnym przejawem tej swoistej odrębności mogło być otwarte potępienie 
przez Ceauşescu w dniu 21 sierpnia 1968 roku inwazji pięciu państw Układu Warszawskiego na Czechosłowację ${ }^{1}$. Były także inne, choć już bardziej „stonowane” momenty i gesty wyróżniające Rumunię w Bloku Wschodnim: niezerwanie stosunków dyplomatycznych z Izraelem po „wojnie sześciodniowej” 1967 roku, nawiązanie, bez konsultacji choćby „z bratnią” Polską, stosunków dyplomatycznych z RFN w 1968 roku, bliższe od innych sojuszników Kremla stosunki z Chińską Republiką Ludową, krytyka sowieckiej inwazji na Afganistan w 1979 roku, nieprzyłączenie się do bojkotu przez państwa realnego socjalizmu igrzysk olimpijskich w 1984 roku w Los Angeles, czy wreszcie niepopieranie planów interwencji wojsk Układu Warszawskiego w Polsce późną jesienią 1980 roku. Ta swoista rumuńska ,indywidualizacja” w polityce zagranicznej nie spowodowała jednak żadnych trwałych pęknięć europejskiej ,wspólnoty państw socjalistycznych” i generalnie jest dziś postrzegana bardziej jako przejaw pewnej - nakierowanej głównie na efekt propagandowy - gry politycznej Bukaresztu². Ciagłe podkreślanie przez Cauşescu konieczności uszanowania narodowej suwerenności i nieingerencji mogło sugerować, że również w stosunku do przemian w Polsce w 1989 roku Bukareszt będzie chciał zachować dystans czy rezerwę. Okazało się, że było zupełnie odwrotnie. Przy generalnie negatywnym - niezależnie od ducha gorbaczowowskiej pieriestrojki - stosunku władz „,krajów demokracji ludowej” do tych wydarzeń, w świetle działań dyplomacji SRR można nawet dojść do wniosku, że reakcja władz rumuńskich najbardziej się wówczas pod tym względem wyróżniała.

$\mathrm{Na}$ pierwszy rzut oka Ceauşescu sam niejako zaprzeczał swojej głoszonej od lat pryncypialnej zasadzie nieingerencji w wewnętrzne sprawy innych „bratnich krajów”, co dawniej pozwalało mu zdobywać aplauz za granica, dodatkowo wzmacniając jego megalomanię. Z drugiej jednak strony, w 1989 roku zarówno on, jak i pozostali komunistyczni liderzy, także z PRL, zdawali sobie sprawę, że obserwowane tym razem w Bloku Wschodnim przemiany mogą pójść w zupełnie innym kierunku niż podobne próby w latach poprzednich, choć ich ostatecznego kształtu i kierunku nikt oczywiście, nie tylko w kręgach władzy, nie był w stanie jeszcze wówczas przewidzieć. Ceauşescu był jednak nimi coraz bardziej poirytowany, gdyż widział w nich - jak się okazało zupełnie słusznie - prostą drogę do zniszczenia komunizmu. Jego negatywne reakcje dotyczyły także pasywnej wobec przemian w Polsce postawy Kremla, tym bardziej że od dłuższego czasu rumuński przywódca krytycznie wypowiadał się również o kierunkach zmian w ZSRR ${ }^{3}$. W tym kontekście trudno jest porównywać jego postawę w 1968 i 1989 roku, gdyż w okresie „Praskiej Wiosny” nie groził mu wybór między dalszym trwaniem komunizmu a własnym upadkiem i końcem tego systemu.

\section{W cieniu Okrąglego Stołu}

Wzrost zainteresowania Rumunii sytuacją w Polskiej Rzeczypospolitej Ludowej nastąpił - podobnie zresztą jak w innych krajach - od końca stycznia 1989 roku, czyli wówczas gdy władze Polskiej Zjednoczonej Partii Robotniczej i Lech Wałęsa ostatecznie

\footnotetext{
${ }^{1}$ Zob. L.Betea, F.-R.Mihai, I.Țiu, 21 august 1968. Apoteoza lui Ceauşescu, wyd. II, București 2018.

${ }^{2}$ Szerzej zob. np. A. Burakowski, Geniusz Karpat. Dyktatura Nicolae Ceauşescu 1965-1989, Warszawa 2008.

${ }^{3}$ Th. Kunze, Ceauşescu. Piekło na ziemi, Warszawa 2016, s. 371-372.
} 
porozumieli się w sprawie przystapienia do rozmów Okragłego Stołu, w których mieli uczestniczyć przedstawiciele rządu i opozycja. Dyplomacja rumuńska wskazywała, że PZPR - dążąc do budowy pluralistycznego społeczeństwa, „odnowienia” socjalizmu, reformy gospodarki, a także rozważając reaktywację „Solidarności” - świadomie rezygnuje ze swej przewodniej roli, zatem władzy w organach państwowych, administracji i gospodarce. Centrala Ministerstwa Spraw Zagranicznych w Bukareszcie informowała swoją placówkę warszawską, że również strona radziecka uważnie monitoruje zarówno sytuację w Polsce, jak i na Wegrzech, w kontekście działań podejmowanych w obu krajach po linii politycznego pluralizmu. Stwierdzano, że według Kremla, partia rządząca w Polsce powinna szukać rozwiązań, które pozwoląjej nie ulec innym siłom politycznym, gdyż w przeciwnym razie moga pojawić się komplikacje ${ }^{4}$.

Tymczasem rząd rumuński ostro zareagował, gdy w związku z wyraźnie już rozluźniającą się atmosferą społeczno-polityczną w PRL, 1 lutego 1989 przed ambasadą SRR w Warszawie demonstrowano przeciwko działaniom reżimu Ceauşescu wobec mniejszości węgierskiej w Siedmiogrodzie (w ramach tzw. systematyzacji wsi). Jak raportował ambasador Ion Teşu, najpierw w godzinach rannych z samochodu na polskich numerach rejestracyjnych zostały wrzucone na dziedziniec ambasady ulotki w języku rumuńskim, węgierskim i polskim. Z kolei po południu grupa około 25 protestujacych, $w$ większości młodych, wyrażała sprzeciw przed ambasadą, wykrzykujac obraźliwe hasła przeciwko naszemu krajowi. Ambasador zwracał uwagę na zbyt późną - jego zdaniem - reakcję służb porządkowych, które interweniowały dopiero po jego monitach w polskim MSZ5. W Bukareszcie Rumuni złożyli protest na ręce ambasadora PRL, Jerzego Woźniaka, zaś Teşu otrzymał ze swojej centrali nakaz złożenia protestu polskim władzom, co zrealizował 8 lutego, odwiedzając w Warszawie nie tylko MSZ, ale i Wydział Międynarodowy KC PZPR. Podczas rozmowy w MSZ stwierdził, że demonstracja stanowiła przejaw mieszania się w sprawy wewnętrzne jego kraju, miała inspirację węgierską i była próbą dyskontowania niekorzystnej atmosfery wytworzonej wokół Rumunii w następstwie agresji propagandowej Zachodu zwiazanej z planami systematyzacji terytorialnej, wyrażając ubolewanie, że wydarzenie to miało miejsce w zaprzyjaźnionym państwie, w dodatku przed zbliżającą się 40. rocznicą (10.02.1949) ratyfikacji polsko-rumuńskiego układu o przyjaźni. Wspomniał także o pełnych - zdaniem władz SRR - historycznych zniekształceń relacjach polskiej prasy na temat prowadzonej we wsiach siedmiogrodzkich reformy oraz o planowanej przez Węgierski Instytut Kultury w Warszawie konferencji i wystawie o Siedmiogrodzie i rocznicy Wiosny Ludów. W przekonaniu jego polskich rozmówców $w$ odróżnieniu od protestu wystosowanego przez MSZ SRR wobec naszego ambasadora w Bukareszcie, cała wypowiedź tow. Teşu była utrzymana $w$ spokojnym tonie, świadczyła o jego zrozumieniu specyfiki sytuacji $w$ Polsce $i$ woli niedramatyzowania zaistniałego incydentu. W odpowiedzi strona polska

\footnotetext{
${ }^{4}$ Arhiva Ministerului Afacerilor Exter-ne în Bucureşti (dalej AMAE), Probleme interne din Polonia. Situația socio-politică (dalej PIP), Depesza MSZ w Bukareszcie do Ambasady SRR w Warszawie, 6.02.1989, fond 1989/699, dosar 210/1, k.21.

${ }^{5}$ Ibidem, Relații bilaterale româno-polone (dalej RBRP), Depesza Ambasady SRR w Warszawie do MSZ w Bukareszcie, 1.02.1989, fond 1989/710, dos.220/2, k.3-4; Depesza MSZ w Bukareszcie do Ambasady SRR $w$ Warszawie, 2.02.1989, ibidem, k. 5-5a. Wprowadzana od 1974 r. w SRR systematyzacja wsi obejmowała przymusowe przesiedlenia ludności wiejskiej do osiedli rolniczo-przemysłowych w celu powiększania areału uprawnego i miała być wzorowana na modelu północnokoreańskim.
} 
po wyrażaniu zwyczajowego ubolewania podkreśliła całkowice nielegalny charakter manifestacji, skuteczną interwencję służb porządkowych, podjęte kroki prawne przeciwko niektórym uczestnikom, znikomą liczbę uczestników z kręgów ekstremistycznej opozycji. Polemizowano też z sugestią ambasadora o występowaniu w Polsce nastrojów antyrumuńskich i zapewniano o wadze przyjacielskich stosunków z Rumunią dla władz PRL, ale jednocześnie zaakcentowano potrzebę petnego zrozumienia procesów zachodzacych w polskim życiu politycznym, jego polaryzacji i specyfiki, które moga powodować incydenty niemajace nic wspólnego z naszq [władz PRL - KN] pryncypialna i niezmienna linia wspótpracy z państwami socjalistycznymi. Wzmocniono też ochronę ambasady SRR i poproszono odnośne władze, aby zapobiegały podobnym incydentom w przyszłości ${ }^{6}$.

Można powiedzieć, że opisane wyżej wydarzenia w „bratnim kraju” mogły być dla Bukaresztu pewnym szokiem. Szczególnie musiał dotknąć i zdenerwować Rumunów fakt, że w proteście brali udział przebywający w Polsce studenci węgierscy. Jak wynika z reakcji centrali rumuńskiego MSZ, nie była ona zadowolona z wyłącznie typowo protokolarnej odpowiedzi władz polskich ${ }^{7}$. Z drugiej strony, udział Węgrów w warszawskiej manifestacji mógł być na rękę aktualnej linii propagandowej Ceauşescu, szukającego przyczyn problemów wewnętrznych Rumunii w czynnikach zewnętrznych, w tym przypadku w inspiracjach również dla niego politycznie, ,podejrzanego" Budapesztu, choć sprawy polskie miały wówczas większy ciężar gatunkowy. Niezależnie od tego, władze rumuńskie zdały sobie sprawę, że przemiany polityczne w Polsce są już mocno zaawansowane.

W Wydziale Międzynarodowym KC PZPR ambasador Teşu zapytał dodatkowo o możliwość zrealizowania w 1989 roku wizyty w Rumunii Wojciecha Jaruzelskiego, I sekretarza KC PZPR. Co do zajść w Warszawie uzyskał tam podobną do otrzymanej w MSZ odpowiedź, natomiast kwestię wizyty jego rozmówcy uzależniali od kalendarza politycznego ważnych wydarzeń wewnatrzkrajowych ${ }^{8}$. Choć w tym okresie dla kierujących nadal sterem polskiej dyplomacji władz PZPR stosunki z SRR nie miały już większego znaczenia, starały się one oczywiście unikać zadrażnień, mimo iż co chwila były narażone na pretensje i połajanki ze strony uznawanego przez nie od dawna, jak i przez wiele innych państw za anachroniczny i niereformowalny, reżimu Nicolae Ceauşescu. Poza tym same nie miały już wpływu na narastający w Polsce wzrost aktywności obywatelskiej. Mimo kolejnych zaproszeń Rumunów, nie wchodziła już także w grę podróż do Bukaresztu W. Jaruzelskiego, która w ówczesnych warunkach byłaby dla niego wyłącznie wizerunkową katastrofą.

Zainteresowanie, ale i zaniepokojenie sprawami polskimi w Bukareszcie i w ogóle w Bloku Wschodnim wzrosło po 6 lutego, czyli po rozpoczęciu w Polsce obrad Okrągłego Stołu. Takie rozwiązywanie wewnętrznych problemów w państwie socjalistycznym było dla Ceauşescu nie do przyjęcia, gdyż wszelkie podważanie monopolu partii komunistycznej

\footnotetext{
${ }^{6}$ Archiwum Ministerstwa Spraw Zagranicznych w Warszawie, Departament I, Rumunia (dalej AMSZ, D I, R), Notatka Wydziału Zagranicznego KC PZPR, 8.02.1989, syg. R-2010-1-89, k. 45-46; Pilna notatka z rozmowy z ambasadorem SRR, I. Teşu $w$ dniu 8.02.1989 r., 9.02.1989, syg. D I-R-0-240-1-89, k.7-9; AMAE, RBRP, Depesza Ambasady SRR w Warszawie do MSZ w Bukareszcie, 10.02.1989, fond 1989/710, dos. 220/2, k. 9-10.

${ }^{7}$ Przy fragmencie depeszy Teşu do Bukaresztu z 10.02. z przytaczaną odpowiedzią polskiej strony wyrażającej ubolewanie z powodu zajścia pod ambasadą SRR na marginesie widnieje odręczny dopisek czytającego: powtarza się za każdym razem.

${ }^{8}$ AMSZ, D I, R, Notatka Wydziału Zagranicznego KC, 8.02.1989....
} 
na decydowanie o całokształcie życia obywateli uważał za „reakcję” i imperialistyczną inspirację. Faktycznie polski wzorzec zagrażał pozycji także innych przywódców „Krajów Demokracji Ludowej”, gdyż mógł być dla ich społeczeństw inspiracją do walki o wolność i demokrację, tym bardziej że podobnie głęboki proces przemian rozpoczął się na sąsiednich Węgrzech, i to w sytuacji, gdy wyizolowanie Polski przez „bratnie kraje” było już teraz niemożliwe. W 1989 roku większym problemem dla Bukaresztu, Pragi, Berlina, czy Sofii było jednak to, że tzw. polska specyfika została przez owładnięty duchem pieriestrojki Kreml już dawno zaakceptowana, co oczywiście zachęcało Warszawę do dalszych niezależnych działań. Mimo ostrożnego podejścia do wprowadzanych w ZSRR reform - choć Moskwy nigdy z tego powodu wprost nie atakowano - oraz niewątpliwego rozczarowania postawą władz sowieckich - jakże odmienną od tej z epoki Breżniewa, dyplomacja wymienionych stolic nadal skrupulatnie odnotowywała w tym okresie każdy głos Kremla w sprawach polskich. Stąd też przesłanie wtedy gdy w Polsce dyskutowano nad ponowną legalizacją „Solidarności” (co nastapiło 19 kwietnia) ambasadorowi Teşu - za pośrednictwem Bukaresztu - wskazówki z placówki dyplomatycznej SRR w Moskwie, że strona sowiecka opowiada się u siebie tylko za pluralizmem poglądów, ale nie za pluralizmem związkowym i politycznym ${ }^{9}$, podkreślić miało słuszne stanowisko RPK, negujące strategię przyjętą przez PZPR. 28 marca Teşu otrzymał ze swojej centrali instrukcję, aby nie utrzymywać z „Solidarnością” żadnych kontaktów i nie odpowiadać na jej korespondencję. Akceptowano jedynie łączność z Ogólnopolskim Porozumieniem Związków Zawodowych (Alfreda Miodowcza) ${ }^{10}$. Dyplomacja rumuńska starała się także dyskredytować sytuację w PRL po zarejestrowaniu „Solidarności”. Wskazywała, że zgoda PZPR na dialog z opozycją nie doprowadziła do rozwiązania konfliktów (fala strajków $w$ różnych firmach, w których pracownicy domagajq się podwyżki płac, mimo apeli Lecha Wałęsy o ich zaprzestanie). Przywoływano serię ulicznych demonstracji ekstremistycznej opozycji oskarżajacej Wałęsę o zdradę, pisano o demonstracjach studentów w Krakowie o charakterze antyradzieckim (Rosjanie do domu!), ich starciach z milicją. Rozpoczęta po zakończeniu obrad Okragłego Stołu (5 kwietnia) kampania wyborcza „Solidarności” miała być wspierana z krajów zachodnich, co zresztą nie stanowiło tajemnicy i było przez Polaków akceptowane. Podawano sumy, jakie na wsparcie „Solidarności” przeznaczył Kongres USA i związki zawodowe USA, RFN, Włoch, Belgii. Z drugiej strony stwierdzano, iż była ona lepiej organizowana przez opozycję niż kampania koalicji rządowej ${ }^{11}$.

Po zwycięskich dla „Solidarności” wyborach (4 i 18.06.1989) rumuńskie MSZ zwróciło się do swojej placówki w Warszawie z prośbą o zintensyfikowanie kontaktów z czołowymi czynnikami po linii partyjnej i państwowej, z osobowościami polskiego życia politycznego i kulturalnego (rozmawiano np. z pisarzem Janem Dobraczyńskim z ,prorządowego" Patriotycznego Ruchu Odrodzenia Narodowego), z korpusem dyplomatycznym w celu uzyskania bardziej dokładnych i obiektywnych informacji na temat m.in. sposobu tworzenia nowego rządu w sytuacji, gdy niedawna opozycja będzie jednak w nim uczest-

${ }^{9}$ AMAE, PIP, Depesza MSZ w Bukareszcie do Ambasady SRR w Warszawie, 6.03.1989, fond 1989/699, dos. $210 / 1$, k. 38 .

${ }^{10}$ Ibidem, RBRP, Depesza MSZ w Bukareszcie do Ambasady SRR w Warszawie, 28.03.1989, fond 1989/710, dos. 220/2, k. 22.

${ }^{11}$ Ibidem, Depesze Ambasady SRR w Warszawie do MSZ w Bukareszcie: 2.03, k. 41-42; 29.05, k. 77-78; 1.06 ; k. 80-81; 2.06.1989, k. 83-85. 
niczyć, ewolucji w PZPR, postawy armii polskiej ${ }^{12}$. Zwracano także uwagę na, powszechnie zresztą dostrzegane, nastroje apatii w partii rządzącej, odchodzenie z jej szeregów, głosowanie części członków PZPR i $60 \%$ wojska na listy opozycyjne. Obserwując zanik wpływów politycznych PZPR, jednocześnie przekazywano do centrali informacje o pierwszych wewnętrznych problemach opozycji (odmienne zdania na temat wejścia do rządu generała Czesława Kiszczaka i dalszych losów „Solidarności” jako związku zawodowego, podział na skrzydło „Kuronia” i „Michnika” oraz obawy Kościoła katolickiego o swoją dalszą pozycję pośrednika w politycznym dyskursie). Obszernie poinformowano także Bukareszt o powstaniu w środowiskach związanych z reformatorskim skrzydłem PZPR „Inicjatywy 8 lipca", obawiając się, że ze swoim programem odpolitycznienia przedsiębiorstw produkcyjnych i urynkowienia gospodarki pójdzie ona wyłącznie w kierunku socjaldemokratycznym ${ }^{13}$.

\section{Inicjatywy dyplomatyczne Nicolae Ceauşescu}

W takiej atmosferze odbyło się w dniach 7-8 lipca 1989 roku w Bukareszcie posiedzenie Doradczego Komitetu Politycznego państw stron Układ Warszawskiego. W związku z sytuacją w PRL, w jego kuluarach lider RPK namawiał - zresztą nie pierwszy raz przywódców „bratnich” państw, by jesienią zorganizować nadzwyczajne spotkanie na szczycie partyjnych liderów, które byłoby poświęcone sytuacji politycznej w państwach komunistycznych i w ogóle przyszłości socjalizmu ${ }^{14}$. Jednak w uchwalonym na posiedzeniu wspólnym komunikacie padły znamienne słowa o nieistnieniu jakichkolwiek uniwersalnych modeli socjalizmu czy monopolu na prawdę. Budowa nowego społeczeństwa miała być procesem twórczym, który przebiega w każdym kraju zgodnie z jego warunkami, potrzebami i tradycjami ${ }^{15}$, a w tych sformułowaniach łatwo dostrzec inspirację odrzucającego ostatecznie „,doktrynę Breżniewa” Michaiła Gorbaczowa. Zapewne dziesięć lat wcześniej w pełni utożsamiałby się z nimi także Nicolae Ceauşescu, ale latem 1989 roku bardziej przyklasnęła im Warszawa i Budapeszt, podczas gdy zaniepokojony sytuacją w PRL przywódca SRR wprost zachęcał do odrodzenia doktryny i stworzenia nowego Kominformu. Część komunistycznych przywódców odniosła się do tych planów dość sceptycznie (ZSRR, PRL, WRL), inni zajęli postawę wyczekującą ${ }^{16}$. Jeśli bowiem wcześniejsze obnoszenie się przez Rumunię z własną niezależnością mogło budzić wśród mieszkańców KDL pewne poważanie, a u ich władz irytację, to w tym okresie bliższy układ z coraz bardziej kompromitującym się w swojej polityce wewnętrznej i izolowanym na arenie międzynarodowej

${ }^{12}$ AMAE, PIP, Depesza MSZ w Bukareszcie do Ambasady SRR w Warszawie, 8.06.1989, fond 1989/699, dos. 210/1, k. 89 .

${ }^{13}$ Ibidem, Depesze Ambasady SRR w Warszawie do MSZ w Bukareszcie: 24.06, k. 100; 1.07., k. 107-109; 27.07, k. 117-118, 121. „Inicjatywa 8 lipca”, albo „Ruch 8 lipca”, łączyła część inteligenckich środowisk w PZPR opowiadających się za jej rozwiązaniem i utworzeniem ugrupowania socjaldemokratycznego.

${ }^{14}$ Th. Kunze, Ceauşescu..., s. 368-369.

${ }^{15}$ AMSZ, D I, R, Odpowiedź na stanowisko PKW KC RPK SRR i prezydenta SRR N.Ceauşescu w sprawie oceny aktualnej sytuacji w Polsce, $w$ tym powołania rzqdu PRL, 21 sierpnia 1989, syg. R-1-0-240-3-89, k. 6.

${ }^{16}$ T. Kunze, Ceauşescu..., s. 368-369; J. Rychlík, Politické změny ve Východni Evropě pred 17. listopadem a jejich ohlas v Československu, „Česko-slovenská historická ročenka” 2009, s. 131. 
Nicolae Ceauşescu, powstały przy tym bez protektoratu Moskwy, nie był już raczej po myśli także Pragi, Berlina, czy Sofii. Z drugiej strony można było zauważyć tworzący się - jakby antyreformatorski, nieformalny, konserwatywny - blok przywódców Rumunii, Bułgarii, NRD i Czechosłowacji, dla których treść powyższego komunikatu mogła być rodzajem zasłony przed mieszaniem się ZSRR do ich polityki wewnętrznej.

Tymczasem dalszy rozwój sytuacji w Polsce utwierdzał jedynie Bukareszt w obawach przed wzrostem sił „reakcyjnych”. Rumuni negatywnie reagowali na ustawowe wprowadzanie w Polsce gospodarki rynkowej i brak sukcesów w misji tworzenia rządu przez reprezentanta dotychczasowej władzy, gen. Kiszczaka ${ }^{17}$. Dla Ceauşescu miarka się przebrała, gdy 17 sierpnia Lech Wałęsa ogłosił, że powstanie nowy rząd bez PZPR, złożony z przedstawicieli opozycji, Stronnictwa Demokratycznego i Zjednoczonego Stronnictwa Ludowego, z premierem Tadeuszem Mazowieckim z obozu solidarnościowego, którego 19 sierpnia desygnował na to stanowisko prezydent Wojciech Jaruzelski. Jeszcze tego samego dnia Ceauşescu zaprosił na godzinę 23.00 do swojej willi pod Bukaresztem ambasadora ZSRR w SRR Jewgienija Tiażelnikowa i, w obecności swojego ministra spraw zagranicznych Ioana Totu, zaapelował do BP KC Komunistycznej Partii Związku Radzieckiego, władz sowieckich i osobiście do Gorbaczowa o pilne środki, które należy podjać, aby zapobiec likwidowaniu socjalizmu w Polsce, gdyż sytuacja, w której PZPR dobrowolnie rezygnuje z przewodniej roli w państwie nie jest już jedynie wewnętrzną sprawą Polaków, ale zagraża wszystkim państwom demokracji ludowej, trwałości Układu Warszawskiego i jest na rękę USA i NATO. Zdaniem przywódcy SRR, wspólnota socjalistyczna powinna nie dopuścić do powstania rządu kierowanego przez „Solidarność”; nadal powinien on być kierowany przez PZPR i mieć charakter rządu „ocalenia narodowego”, na bazie OPZZ i wojska. Wyrażał pewność, że ZSRR podejmie odpowiednie kroki w tym kierunku jako państwo odpowiedzialne za los całego światowego socjalizmu, zwrócił również uwagę na fakt obecności wojsk sowieckich w Polsce. Twierdził, że historia nigdy nie zapomni zaprzyjaźnionym partiom i krajom, jeśli dojdzie do zniszczenia socjalizmu w Polsce. Swój apel łączył z chęcią spotkania się z Gorbaczowem (20 sierpnia) na terenie ZSRR. O ile spotkanie na najwyższym szczeblu nie doszłoby do skutku, Ceauşescu proponował dyskusję między innymi liderami obu partii. Zapowiedział również niezwłoczne wystosowanie apelu do przywódców PZPR, aby przekazać im dezaprobatę RPK wobec zachodzących w Polsce wydarzeń, dodać im otuchy i nakreślić rumuńską wizję rozwiązania najbardziej skomplikowanych problemów ją dotykających, oraz drugiego apelu, skierowanego do wszystkich przywódców państw Układu Warszawskiego i wszystkich krajów socjalistycznych z pilną prośbą o podjęcie energicznych wspólnych działań w celu zapobieżenia śmierci socjalizmu w Polsce. Uważał, że po utworzeniu przez PZPR nowego rządu wszystkie kraje socjalistyczne powinny udzielić Polsce znaczącej pomocy ekonomicznej ${ }^{18}$. Jako

\footnotetext{
${ }^{17}$ AMAE, Relațiile politico-diplomatice cu România, Polonia (dalej RPDP), Notatka z audiencji ambasadora PRL u ministra spraw zagranicznych SRR, 5.08.1989, fond 1989/712, dos. 220, k. 16-18; Aspecte alle situatiei interne din Polonia, 25.08.1968, ibidem, k. 68-70.

${ }^{18}$ Zob. np. Soviet Ambassador to Romania E. M. Tyazhel'nikov, Record of a Conversation with N. Ceauşescu and Message for Gorbachev, August 19, 1989, History and Public Policy Program Digital Archive, Rossiiskii Gosudarstvennyi Arkhiv Noveishei Istorii (RGANI), Fond 5, Opis' 102, Delo 80, Listy 107-110. Obtained and translated for Cold War International History Project by Mark Kramer, http://digitalarchive.wilsoncenter.org/ document/121614, [ostatni dostęp 5.06.2020].
} 
pierwszy z treścią apelu zapoznał się ambasador Woźniak, który godzinę po rozpoczęciu spotkania Ceauşescu z Tiażelnikowem został wezwany do siedziby MSZ, gdzie odpowiedzialny za sprawy zagraniczne w KC RPK sekretarz Ioan Stoian w obecności wiceministra spraw zagranicznych Constantina Oancei zarzucił go pretensjami pod adresem kapitulanckiej postawy PZPR. Z upoważnienia swoich władz partyjno-państwowych obaj przekazali polskiemu dyplomacie konkretne uwagi dotyczqce obecnej sytuacji w Polsce, która uważaja za bardzo poważnq. Według przesłanego przez Woźniaka tekstu, Rumuni oświadczali, że nie chcq ingerować w wewnętrzne sprawy Polski, ale powaga wydarzeń wykracza poza wewnętrzne sprawy Polski. Poza tym:

- nawiązując do rezygnacji z tworzenia rządu przez K.[iszczaka] i propozycji powierzenia misji Mazowieckiemu oraz propozycji Wałęsy w sprawie utworzenia rządu bez udziału komunistów (mimo późniejszych modyfikacji) - stanowi to zdaniem RPK rezygnację przez PZPR z kierowniczej roli w państwie,

- umożliwienie dojścia do władzy „S[olidarności]” (utworzenie rządu) jest sprzeczne z naukową rewolucją koncepcji socjalizmu i służy najbardziej reakcyjnym kołom imperialistycznym,

- oświadczają, że jako partia komunistyczna, jako kraj socjalistyczny, nie mogą uznać, że jest to tylko wewnętrzna sprawa Polski. Są zdania, że dotyczy to wszystkich krajów socjalistycznych,

- Polska jest członkiem U[kładu] W[arszawskiego] i depozytariuszem dokumentów UW - zrezygnowanie przez partię ze swej kierowniczej roli stanowi poważny cios dla UW -jest sprzeczne z zadaniami UW, stwarza dla niego poważne zagrożenie i stanowi silne poparcie dla NATO,

- biorąc powyższe pod uwagę, kierownictwo partii i rządu R.[umunii] uważa, że partie komunistyczne i robotnicze krajów socjalistycznych, członków UW, powinny zająć stanowisko i domagać się, aby nie powierzano misji tworzenia rządu „S[olidarności]”,

- uważają, że nowy rząd powinien być utworzony w oparciu o PZPR, OPZZ (7 milionów członków) i inne postępowe demokratyczne siły wspólnie z wojskiem - utworzyć rząd ocalenia narodowego - ocalenia socjalizmu w Polsce,

- wyniki wyborów nie mogą powodować zaprzepaszczenia interesów narodu i klasy robotniczej (jako przykład właściwego działania przytoczył Panamę - mały kraj, który unieważnił wybory, nie poddając się naciskowi USA),

- kierownictwo RPK (PKW i N[icolae] C[eauscescu]) osobiście postanowiło, aby jeszcze tej nocy zwrócić się do kierownictwa PZPR, do B[iura] P[olitycznego] i do kierownictw wszystkich partii komunistycznych i robotnicznych państw UW. Wyraża poważne zaniepokojenie sytuacją i sposobem jej rozwiązywania w Polsce. Zwrócić się z apelem do BP PZPR i wyrazić nadzieję, że zostanie zrobione wszystko, co jest potrzebne, aby działać przeciw kursowi likwidacji socjalizmu w Polsce,

- sprawy socjalizmu wymagaja, aby partie komunistyczne w tym szczególnie poważnym momencie działały jednolicie, aby zapobiec oddaniu władzy robotniczo-chłopskiej w ręce kół reakcyjnych,

- domagają się od klasy robotniczej i sił postępowych obrony socjalizmu w Polsce i działań przeciw imperializmowi,

- kierownictwo RPK (PKW i N[icolae C[ausescu]) postanowiło zwrócić się do kierownictwa PZPR i do BP, do kierownictw partii krajów UW i innych krajów socjalistycznych, by wyrazić poważne zaniepokojenie oraz aby wspólnie zadziałać w sprawie zapobieżenia poważnej sytuacji w Polsce, w sprawie obrony socjalizmu i narodu polskiego. 
Rumuni prosili w imieniu Politycznego Komitetu Wykonawczego RPK i N. Cauşescu, aby ich stanowisko przekazać niezwłocznie do Warszawy i oczekiwali na opinię PZPR w tej sprawie $^{19}$. Zgodnie z zapowiedzią list o podobnej treści, wzywający kraje socjalistyczne do okazania PZPR skutecznego wsparcia, uczynienia wszystkiego, co konieczne, i zajęcia zdecydowanego stanowiska w celu niedopuszczenia do objęcia w Polsce, niezależnie od wyników wyborów, urzędu premiera przez reprezentanta „Solidarności”, wręczano ich ambasadorom do godziny 3 nad ranem ${ }^{20}$. Przekaz Ceauşescu był jasny - ustanowienie premierem działacza „Solidarności” oznaczało otwarcie drogi do likwidacji socjalizmu także w innych państwach i zagrożenie dla Układu Warszawskiego, a więc pokoju w Europie.

21 sierpnia Sekretariat Wydziału Międzynarodowego KC PZPR przygotował obszerną odpowiedź, w której podważał argumentację Bukaresztu - faktycznie zresztą zupełnie oderwaną od rzeczywistości - oczywiście w mocno dyplomatycznym tonie. Rozumiejąc intencje i troskę KC RPK o los socjalizmu w Polsce, PZPR odrzucała oceny i wnioski zawarte w rumuńskim oświadczeniu jako nieodpowiadające aktualnym realiom i podtrzymała swoje przekonanie co do obranej drogi jako jedynie stusznej, dla której nie ma alternatywy. Podkreślano suwerenność narodu polskiego do decydowania o składzie i sposobie tworzenia własnego rządu, przypominano ogólną zasadę prawa międzynarodowego niemieszania się w wewnętrzne sprawy innych państw, bijąc jakby w ten sposób władze SRR ich własną bronią poprzez przypominanie, że w przeszłości eksponowały tę zasadę, czego niewątpliwie najbardziej jaskrawym przykładem jest odmowa wzięcia przez Rumunię udziału w interwencji w Czechosłowacji w 1968 roku. Przypomniano też o ostatnich - wspomnianych wyżej - postanowieniach z bukareszteńskiego posiedzenia DKP Układu Warszawskiego. Jednocześnie sporo miejsca poświęcono przekonywaniu Rumunów, iż podjęte przez PZPR decyzje nie oznaczają tracenia z pola widzenia generalnych interesów socjalizmu jako formacji społecznej, a zgoda na zmiany nie oznacza rezygnacji z wpływania na kształtowanie polityki państwa, odpowiadajacej interesom socjalizmu i oczekiwaniom $n a r o d u$. Podkreślano rolę partii w społeczeństwie, w organach państwa, administracji terenowej, w siłach zbrojnych i porządkowych oraz zapewniano, że uczyni ona wszystko, aby zachowana była również silna pozycja PZPR $w$ tworzonym obecnie rzqdzie, a gwarantem ciagłości ustrojowej państwa polskiego i ewolucyjnego charakteru socjalistycznych przemian miał być wybrany 19 lipca na urząd prezydenta PRL gen. Wojciech Jaruzelski, dysponujący szerokimi uprawnieniami konstytucyjnymi. Władze polskie szczególnie mocno akcentowały wierność Polski zobowiazaniom sojuszniczym w ramach Układu Warszawskiego, będącego nadal gwarantem jej bezpieczeństwa, w sytuacji gdy również siły polityczne spoza PZPR i uzgodnienia Okragłego Stołu uznawały pozostawanie Polski na gruncie członkostwa $w$ UW. Zarzuty rumuńskie na temat zagrożenia tego stanu oraz interesów Rumunii na skutek przemian zachodzących w Polsce i w innych krajach socjalistycz-

${ }^{19}$ AMSZ, D I, R, Depesza ambasady PRL w Bukareszcie do MSZ w Warszawie, 20.08.1989, syg. D I 0-2950/89, k. 12-13 a.

${ }^{20}$ AMAE, RPDP, Apel przywództwa RPK i Rumunii do BP i KC partii komunistycznych, projekt, fond 1989/712, dos. 220, k. 71-74; Transcript of Meeting of the Executive Politburo of the Central Committee of the Romanian Communist Party, August 21, 1989, History and Public Policy Program Digital Archive, Stenograma şedinței Comitetului Politic Executiv al C.C. al P.C.R. din ziua de 21 august 1989, Arhiva Nationale Romanesti, Fond CC al PCR, Sectia Cancelarie, Dosar Nr. 57/1989, f. 1-6. Translated for CWIHP by Larry Watts, http:// digitalarchive.wilsoncenter.org/document/121611 [ostatni dostęp 4.06.2020]. 
nych uznano za niczym nieuzasadnione. Przeciwnie, stwierdzano, że będą one służyć umocnieniu pozycji socjalizmu w świecie, przywróceniu żywotności idei socjalizmu i jej siły przyciagania i tym samym nie dadza RPK podstaw wychodzenia również wobec innych partii komunistycznych z tego rodzaju ocenami $i$ wnioskami [...]. Oczekując więc poszanowania zasad uzgodnionych przez państwa Układu Warszawskiego, spodziewano się innego wsparcia niż to proponowane teraz przez RPK, deklarując jednocześnie gotowość do podzielenia się z Rumunami własnymi doświadczeniami, co miało pozwolić zrozumieć im polskie uwarunkowania i przewartościować dotychczasowe oceny polskich reform ${ }^{21}$. Treść przytoczonego dokumentu, celowo odwołująca się do szerszego kontekstu przemian w Bloku Wschodnim, może być przykładem nie tylko sztuki peerelowskiej dyplomacji roku 1989, generalnie opowiadającej się za linią reform reprezentowaną przez gen. Jaruzelskiego, ale i kolejną wykładnią poglądów i planów politycznych wciąż jeszcze formalnie rządzącej Polską ekipy PZPR, z całym jej administracyjnym i siłowym (wojsko) zapleczem.

Wkrótce okazało, że jeszcze przed wręczeniem w Warszawie polskiej odpowiedzi ambasadorowi Teşu, ambasador Woźniak został ponownie wezwany do I. Stoiana (tym razem o godzinie 13.00), który w nieco innym niż dwa dni wcześniej tonie poinformował go, iż dzięki komunikatowi Polskiej Agencji Prasowej kierownictwo partii SRR zapoznało się już z motywacją KC PZPR odnośnie do utworzenia nowego rządu i prosił o natychmiastowe poinformowanie Warszawy o następującym nowym oświadczeniu swoich władz:

- w imieniu KC RPK-PKW wyrażają [one] pełną solidarność z PZPR, z jej kierownictwem, z siłami postępowymi, z klasą robotniczą i całym narodem polskim,

- kierownictwo RPK jest gotowe w układzie bilateralnym lub wspólnie z innymi państwami socjalistycznymi pracować nad programem działań dla wsparcia narodu polskiego, łącznie z programem poparcia ekonomicznego, finansowego i politycznego, aby Polska przewyciężyła trudną sytuację i nadal kroczyła drogą socjalizmu i aby wypełniała nadal swoją rolę w UW i RWPG, i w życiu międzynarodowym,

- zrozumieli [Rumuni - KN] z deklaracji KC PZPR, że konieczne jest utworzenie rządu szerokiego porozumienia narodowego lub szerokiej koalicji,

- popierają stanowisko PZPR. Dlatego uważają, że trzeba uczynić wszystko, aby iść w tym kierunku. Jeśli nie jest możliwe, aby premierem był członek PZPR, to funkcję tę należy powierzyć przedstawicielowi OPZZ lub innej osobistości politycznej, lecz nie „S”. W tym rządzie PZPR powinna nadal odgrywać decydującą rolę dla zabezpieczenia dalszego kroczenia drogą socjalizmu oraz wypełniania obowiązków wynikających z udziału w UW i RWPG.

- rozumieją, że w ramach takiego rządu wielkiej koalicji jest konieczność udziału „S”, lecz PZPR musi zachować dominującą rolę.

- rząd taki winien reprezentować interesy całego narodu. Winien być rządem robotniczo-chłopskim, zdolnym zjednoczyć wszystkie siły dla zapewnienia budowy socjalizmu, dla obrony i umacniania niepodległości Polski,

- RPK, rząd i naród R.[umunii] są gotowi udzielić pełnego poparcia PZPR i narodowi polskiemu, aby utrzymać drogę socjalizmu, aby Polska nadal odgrywała swoją rolę w świecie ${ }^{22}$.

\footnotetext{
${ }^{21}$ AMSZ, D I, R, Odpowiedź na stanowisko PKW KC RPK..., k. 3-6.

${ }^{22}$ AMSZ, D I, R, Depesza ambasady PRL w Bukareszcie do MSZ w Warszawie, 21.08.1989, syg. D I 0-2969/89, k. 11-11 a.
} 
Byłoby naiwnością sądzić, że tak szybka zmiana stanowiska Bukaresztu wynikała jedynie z przekazu PAP, choć było już wiadomo, że reprezentanci PZPR otrzymają jednak m.in. tekę ministra obrony i spraw wewnętrznych. W tym samym dniu nadeszła bowiem do Ceauşescu również odpowiedź z Moskwy, podważająca sens organizacji spotkania liderów partii. W głębokim przekonaniu Kremla każda ingerencja z zewnątrz, tym bardziej użycie sity jest nie tylko niemożliwe, ale absolutnie niedopuszczalne. Byłoby to całkowicie nie do przyjęcia dla narodu polskiego. Nasze narody, narody świata potepityby takie działania z naszej strony, niezależnie od argumentów, którymi je motywowaliśmy. Sowieci wskazywali, że istnieją jednak pewne plusy nowej sytuacji, myśląc o ministrach z PZPR, którzy znaleźli się w rządzie Mazowieckiego, a za jedyny sposób pomocy polskiej partii uznali zacieśnienie z nią więzi i pogłębienie współpracy gospodarczej. Poza tym Gorbaczow wymawiał się niemożnością dokonania zmian w swoim kalendarzu obowiązków oraz pytał retorycznie o reakcję innych przywódców krajów zaprzyjaźnionych na plany takiego nagłego, wyłącznie bilateralnego spotkania. Zaproponowano Rumunom co najwyżej ewentualne robocze zebranie szefów dyplomacji obu państw, aby omówić interesujące ich problemy ${ }^{23}$. W podobnym duchu była skonstruowana również rezolucja BP KC KPZR, stwierdzająca, że pomysł zwołania forum liderów partii komunistycznych w sprawie Polski niewatpliwie zostałby wykorzystany przez , Solidarność” $i$ inne środowiska opozycyjne jako podstawa do przedstawienia PZPR jako sity reprezentujacej interesy partii i państw zagranicznych, a nie interesy Polski. Nie oznaczało to zupełnego pogrzebania idei spotkania „bratnich partii”, ale na razie każda z naszych partii i każde z naszych państw jest teraz $w$ stanie samodzielnie podjać decyzję co do pomocy Polsce, bez potrzeby odbywania wielostronnego spotkania ${ }^{24}$. Po raz kolejny więc odrzucono propozycję Ceauşescu, mogącą być w ówczesnych warunkach faktycznie jedynie przysłowiową wodą na młyn dla polskiej opozycji, a niedźwiedzią przysługą dla PZPR, która znalazłaby się w Polsce pod pręgierzem oskarżeń o zdradę i szukanie pomocy za granicą przeciwko woli narodu.

Tego samego dnia na zwołanym posiedzeniu Biura Politycznego KC RKP Ceauşescu zapoznał jego członków z sytuacją, korespondencją i projektem rumuńskiej „odpowiedzi na odpowiedź" strony sowieckiej. Przede wszystkim podkreślono, że doprowadzenie wreszcie do spotkania partii komunistycznych i robotniczych w sprawie Polski i nie tylko stanowiłoby potężna demonstracje jedności naszych krajów socjalistycznych, potwierdzenie ich solidarności i zdecydowania na rzecz umocnienia tej solidarności. Ale Ceauşescu stwierdził też, że orientacja Polaków jest zgodna z orientacja Zwiazku Radzieckiego, PZPR działa według rad płynących z Moskwy, które jego zdaniem były błędne, gdyż nie odpowiadały interesom Polski i sprawie socjalizmu i otwierały droge „Solidarności”, będącej agenturq zagranicznego imperializmu, przede wszystkim Stanów Zjednoczonych. Liczył, że pod wpływem jego argumentacji Kreml zmieni zdanie i przekona władze PZPR do wyboru innej opcji, gdyż Polska, podobnie jak pół wieku wcześniej, stała się teraz obiektem gry mocarstw. W każdym razie nalegamy - dodawał Ceauşescu, aby do Bukaresztu przybył

${ }^{23}$ AMAE, RPDP, Odpowiedź przywództwa sowieckiego na apel Ceauşescu do Gorbaczowa, odpis, 21.08.1989, fond 1989/712, dos. 220, k. 75-76.

${ }^{24}$ Zob. Resolution of the CPSU CC Politburo No. 132, Regarding the Appeal of Code. Ceauşescu, August 21, 1989, History and Public Policy Program Digital Archive, RGANI, F. 3, Op. 103, D. 180, L. 63, and RGANI, F. 3, Op. 103, D. 181, L1. 140-141. Translated for CWIHP by Mark Kramer, http://digitalarchive.wilsoncenter. org/document/121621 [ostatni dostęp 5.06.2020]. 
szef dyplomacji ZSRR Eduard Szewardnadze, gdyż należy przekonać przywódców radzieckich do zmiany zdania na temat sytuacji w Polsce ${ }^{25}$.

Ceauşescu wysłał więc do Moskwy odpowiedź, której końcowy - niezwykle istotny - fragment zawierał dodatkowo wyjaśnienie nieporozumienia, jakie w jego przekonaniu powstało w związku ze stwierdzeniem Gorbaczowa, iż użycie siły nie jest możliwe. Jak wiecie - zauważał lider RPK - nasza partia zawsze byla przeciwna jakiejkolwiek interwencji wojskowej w innych krajach i przeciwko użyciu sity, i w tym stanowisku jesteśmy konsekwentni. W rezultacie propozycje, które przedstawilem, nie przewiduja interwencji wojskowej w Polsce, ponieważ nie bytoby to wsparcie dla Polaków i PZPR. Wszystkie nasze rozważania i propozycje uwzględniaja wspólne poparcie partii komunistycznych $i$ robotniczych $w$ braterskich krajach udzielone PZPR $w$ celu zintensyfikowania walki politycznej, wzmocnienia sit rewolucyjnych i postepowych walczacych o obronę socjalizmu $w$ Polsce. Poza tym Ceauşescu prezentował swój znany pogląd o możliwości objęcia teki premiera w PRL przez reprezentanta OPZZ. Ponownie też zaproponował zorganizowanie, w końcu sierpnia lub na początku września, nadzwyczajnego spotkania przywódców partii i krajów socjalistycznych, w celu stworzenia programu wspierającego rozwój gospodarczy i polityczny Polski ${ }^{26}$.

Tak więc kiedy wieczorem 21 sierpnia ambasador Teşu stawił się u sekretarza KC PZPR Włodzimierza Natorfa, któremu towarzyszyli jego zastępca Krzysztof Ostrowski i wiceminister spraw zagranicznych Bolesław Kulski, Polacy - mający już informację o ponownej rozmowie Woźniaka i Stoiana - oświadczyli reprezentantowi SRR, że odnotowali z zadowoleniem złagodzenie tonu $i$ wyrażone zrozumienie dla działań PZPR. Jednak $i$ to [kolejne] oświadczenie - kontynuował Natorf - zawiera oceny, z którymi nie możemy się zgodzić. Równocześnie z niepokojem odnotowujemy, iz prasa rumuńska, w tym partyjna, opublikowaty artykuty zbieżne $w$ argumentacji z oświadczeniem z 19.08. Po poinformowaniu Teşu o konieczności przekazania polskiego stanowiska także innym członkom Układu Warszawskiego, rumuński ambasador oświadczył, że przekaże je niezwłocznie do Bukaresztu i podziękował za regularne informacje otrzymywane z KC PZPR, które przesyta kierownictwu $R P K^{27}$.

Analizując poczynania dyplomacji rumuńskiego przywódcy w 1989 roku, wielu obserwatorów, łącznie z władzami PZPR, zadawało sobie zapewne pytanie o rozumienie użytego przez niego sformułowania o uczynieniu wszystkiego, co konieczne, w celu uratowania socjalizmu, zaś Moskwa o sens jego aluzji na temat obecności wojsk sowieckich w Polsce. Inaczej mówiąc, czy przywódca RPK nie sugerował - i nie popierał czasem między wierszami - konieczności ewentualnej interwencji wojskowej Polsce, tym bardziej że z przytoczonej wyżej reakcji Kremla i stanowczego rumuńskiego dementi wynika, iż Sowieci właśnie w ten sposób to odczytali. Sprawa ta od dawna była przedmiotem dociekań i dyskusji zainteresowanych tematem badaczy i generalnie są oni podzieleni na zwolenników i przeciwników tezy o opowiadaniu się Ceauşescu za powtórką scenariusza czecho-

${ }^{25}$ Transcript of Meeting of the Executive Politburo of the Central Committee of the Romanian Communist Party, August 21, 1989...; Resolution of the CPSU CC Politburo No. 132.... [ostatni dostęp 5.06.2020].

${ }^{26}$ AMAE, RPDP, Odpowiedź Ceauşescu na list przywództwa sowieckiego z 21 sierpnia 1989, odpis, 21.08.1989, fond 1989/712, dos. 220, k. 77-79.

${ }^{27}$ AMSZ, D I, R, Notatka z rozmowy Sekretarza KC PZPR Włodzimierza Natorfa z Ambasadorem Socjalistycznej Republiki Rumunii Ionem Teşu, 21.08.1989, syg. 1-0-240-3-89, k. 1. 
słowackiego z 1968 roku, choć w tamtym okresie on sam był temu przeciwny. Łatwiej przychodzi zaprzeczać teoriom idącym w kierunku opowiadania się za interwencją militarną, gdyż nie zachowały się, poza kilkoma wspomnianymi wyżej apelami i tłumaczeniami Ceauşescu, żadne rumuńskie dokumenty na ten temat, a Rumunia podkreślała zawsze zasadę nieingerencji w sprawy wewnętrzne innych państw i, niezależnie od związanych z Polską obaw, wyraźnie chciała być tak nadal odbierana. Poza tym na oczekiwane przez Bukareszt szybkie zwołanie konferencji „,bratnich” partii nie godziła się Moskwa i to bardziej jej oraz Polsce i Węgrom było na rękę podsycanie wrażenia groźby praktycznego powrotu do doktryny Breżniewa, dzięki czemu przeciwnicy reform w ich krajach tracili szybciej grunt pod nogami. Wymowa polskiej riposty była pod tym względem dość oczywista. Z drugiej strony, należy zauważyć, że choć Rumunia nie była od dawna aktywnym członkiem Układu Warszawskiego, retoryka Ceauşescu, idąca w podobnym kierunku jak wypowiedzi sąsiadów Czechosłowacji w 1968 roku, oraz zaskakujące na pierwszy rzut oka przypominanie władzom ZSRR o jego ,,powinnościach” wobec ,światowego socjalizmu” wskazywały, że Ceauşescu był coraz bardziej zdeterminowany, a potem zdesperowany w bronieniu systemu, na tyle, że cztery miesiące później wybrał scenariusz chiński w działaniach przeciwko własnemu narodowi ${ }^{28}$. Warto jednak dodać, że sytuacja realnego socjalizmu w 1989 roku była zupełnie inna niż w 1968 czy w latach 1980-1981 i powstanie okoliczności, które mogły przekuć w czyn apele Geniusza Karpat, oraz być może niewypowiedziane wprost wezwania do akcji zbrojnej w Polsce nie wchodziły już w rachubę.

Po powołaniu 24 sierpnia Tadeusza Mazowieckiego na urząd premiera szanse na realizację planów rumuńskich zaczęły coraz szybciej spadać, co potwierdzała m.in. informacja przekazana 28 sierpnia w Bukareszcie przez radzieckich ambasadorowi Woźniakowi o bezskutecznych zabiegach podejmowanych przez ministra spraw zagranicznych SRR Ioana Totu, by zorganizować spotkanie Nicolae Ceauşescu z Gorbaczowem. Rozmawiał on jedynie z szefem dyplomacji ZSRR Eduardem Szewardnadze w kurorcie Picunda nad Morzem Czarnym w Abchazji, ale również i ten polityk nie widział potrzeby dyskutowania w omawianej materii ${ }^{29}$. Jak wiemy, PZPR otrzymała ostatecznie w rządzie Mazowieckiego 4 teki ministerialne, czyli nawet więcej niż SD i tyle samo co ZSL, w tym tak istotne w kontekście powyższego stanowiska rumuńskiego resorty, jak Ministerstwo Obrony Narodowej i Ministerstwo Spraw Wewnętrznych, na co w panujących wówczas realiach geopolitycznych strona ,solidarnościowa” wyraziła zgodę, podobnie jak i na status quo w odniesieniu do kwestii Układu Warszawskiego i RWPG. To uspokoiło na razie i inne „bratnie” stolice i zmniejszyło ich motywację do podejmowania inicjatywy Ceauşescu, choć obawiały się eksportu polskiego modelu do własnych krajów ${ }^{30}$. Władze PZPR mogły być zadowolone. Stąd tego samego dnia ambasador Woźniak, jakby podsumowując całą

\footnotetext{
${ }^{28}$ Zob. zwłaszcza interesującą dyskusję i polemikę na ten temat: Did Nicolae Ceauşescu Call for Military Intervention Against Poland in August 1989?; Continuing Debate: Ceauşescu's Appeal for Joint Warsaw Pact Action on 19 August 1989 w ramach projektów CWIHP, Wilson Center, e-Dossier No 60; 61, https://www.wilsoncenter.org/publication/did-nicolae-ceausescu-call-for-military-intervention-against-poland-august-1989; https:// www.wilsoncenter.org/publication/continuing-debate-ceausescus-appeal-for-joint-warsaw-pact-action-19-august1989 [ostatni dostęp 5.06.2020].

${ }^{29}$ AMSZ, D I, R, Depesza ambasady PRL w Bukareszcie do MSZ w Warszawie, 28.08.1989, syg. D I 0-3056/89, k. 9 .

${ }^{30}$ J. Rychlík, Politické změny ve Východni Evropě..., s. 132.
} 
sprawę, już wprost bez ogródek stwierdzał, że głównym powodem tak ostrej reakcji $R$.[umunów] na wydarzenia w Polsce jest obawa wpływu na opinię publiczna w kraju, którego władza stosujaca politykę izolacji społeczeństwa, propagandy sukcesu, przy znanym niskim poziomie życia, obawia się wszelkich zmian. Prasa rumuńska nie podała informacji na temat wyboru nowego premiera w Polsce, a zdaniem Woźniaka, obserwuje się u Rumunów pewien zawód, że ich ostrzeżenie nie miało wpływu na wybór M. [azowieckiego] oraz obawy o dalszy rozwój wypadków w P. [olsce] ${ }^{31}$. Ceauşescu przełknął więc gorzką pigułkę i chyba zrozumiał, że wbrew stale utrzymywanej na użytek wewnętrznej propagandy atmosferze, nie odgrywa już żadnej większej roli politycznej także w obozie państw Bloku Wschodniego, choć nie jest pewne, czy rozumiał tego przyczyny, w sytuacji gdy jego przekonanie o upadku komunizmu w PRL miało faktycznie realne podstawy.

Chcąc zatrzeć niekorzystne wrażenie i negatywne skojarzenia, jakie powstały w związku z powyższymi działaniami władz RPK, również wśród zachodniego korpusu dyplomatycznego w Bukareszcie, Rumuni starali się teraz tłumaczyć, że intencją ich posłania było zainicjowanie i zasugerowanie indywidualnej pomocy moralnej, politycznej $i$ materialnej poszczególnych partii dla Polski, natomiast nigdy nie myśleli o żadnych formach zbiorowej pomocy. Zdaniem polskiej placówki w Bukareszcie ta zmiana form $i$ wyjaśniania była efektem reakcji Warszawy na rumuńskie propozycje ${ }^{32}$. Choć było to stwierdzenie nieco na wyrost, przekonywać o tym miały Polaków również prywatne opinie dziennikarzy rumuńskich przy okazji urządzonej w Ambasadzie PRL w Bukareszcie wystawy o udziale Polaków w II wojnie światowej i zorganizowanej 31 sierpnia konferencji prasowej. Mieli bowiem oni wyjaśniać, że ostry komentarz „Scintei” (Strzała) - organu RPK, zamieszczony w numerze z 20 sierpnia, na temat spraw polskich otrzymali z góry i wynikał on z zaniepokojenia oddaniem stanowiska premiera i deklaracjami Wałesy o wyeliminowaniu PZPR. Teraz jednak uważali, że stanowisko RPK pokrywa się ze stanowiskiem PZPR, które mieli popierać w całej rozciągłości. Można było jednak zauważyć ogólną blokadę informacji zagranicznych przez władze rumuńskie $^{33}$. 5 września podczas swego pobytu w Belgradzie minister Totu poprosił o spotkanie z przebywającym tam również ambasadorem PRL Tadeuszem Olechowskim i - według relacji tego ostatniego - $w$ tłumaczacym się tonie nawiązał do rumuńskiego wystąpienia w sprawach polskich. Dawat do zrozumienia - depeszował Olechowski - ze $w$ naszej odpowiedzi zabolat ich zwlaszcza zarzut ingerencji w nasze sprawy wewnętrzne. Obszernie uzasadniat, że nie odstapiq nigdy od poszanowania tej zasady oraz niestosowania sity. Intencja tego wystapienia było udzielenie moralnego poparcia polskim siłom prosocjalistycznym, a wynikać ono miało przede wszystkim z doniesień o wspieraniu „Solidarności” przez USA i warunkach pomocy, które prezydent George Bush stawiał podczas swojej lipcowej wizyty w Warszawie. Niewątpliwie zadowolony z takiego obrotu sprawy polski dyplomata ponownie celowo nawiązał w tej rozmowie do czułego dla Rumunów punktu, czyli głoszonych wcześniej przez nich zasad nieingerencji

${ }^{31}$ AMSZ, D I, R, Depesza ambasady PRL w Bukareszcie do MSZ w Warszawie, 28.09.1989, syg. D I 0-3055/89, k. 10.

${ }^{32}$ Ibidem, Depesza ambasady PRL w Bukareszcie do MSZ w Warszawie, 30.08.1989 (wg informacji przekazanej przez ambasadora Węgier), syg. D I 3080/89, k. 8.

${ }^{33}$ Ibidem, Depesza Ambasady PRL w Bukareszcie do MSZ w Warszawie, 31.08.1989, syg. D I 0-3104/89, k. 7. 
oraz do wspomnianego wyżej komunikatu z lipcowej narady w Bukareszcie i związanego z tym zaskoczenia Polski ich stanowiskiem oraz planami zwołania konferencji. Dał także do zrozumienia, że stanowisko rumuńskie nie znalazło uznania wśród większości państw socjalistycznych. Jednocześnie podkreślił trwałość więzi Polski z Układem Warszawskim, co miał potwierdzać także premier T. Mazowiecki. Argumentację Olechowskiego Totu miał przyjmować bez polemiki, tłumacząc, iż sytuację w Polsce znają z drugiej ręki, co było również swego rodzaju chęcią załagodzenia napięcia. Rumuński polityk wypytywał także o kwestie spłaty polskich długów, dotrzymywania przez „Solidarność” zobowiązań traktatowych, o przyszłość stosunków dwustronnych (Olechowski zapewniał o chęci ich rozszerzenia). Z polecenia N. Ceauşescu Totu prosił także o przekazanie pozdrowień W. Jaruzelskiemu i Mieczysławowi Rakowskiemu. Podsumowując spotkanie, polski minister stwierdził, że odpowiedź na rumuńskie stanowisko kanałem partyjnym przyniosła pożądany skutek. Według niego, celem Totu, poza chęcią załagodzenia ogólnego negatywnego wrażenia powstałego po ogłoszeniu tego stanowiska - było także dążenie do uniknięcia ew. [entualnej] izolacji Rumunii $w$ tej kwestii ${ }^{34}$. Warto dodać, że na prośbę władz polskich obie strony zrezygnowały z organizowania u siebie dni kultury drugiego kraju, co Warszawa motywowała trudnościami finansowymi, a co strona rumuńska przyjąć miała ze zrozumieniem i chyba z zadowoleniem ${ }^{35}$.

\section{Po powolaniu rządu Tadeusza Mazowieckiego}

Powołanie przez nowy polski sejm 12 września 1989 roku rządu Tadeusza Mazowieckiego oznaczało coraz bardziej realne fiasko omawianych wyżej rumuńskich inicjatyw, jak i ewentualnych alternatywnych spekulacji z tym związanych w innych państwach Bloku Wschodniego. Chociaż od lata 1989 roku stosunki rumuńsko-polskie pozostawały napięte, można było jednak wyraźnie zauważyć, że od połowy września we władzach rumuńskich następowała pewna zmiana opinii na temat wydarzeń w PRL, co wynikało głównie z faktu, iż do nowego rządu w Warszawie weszli członkowie PZPR, obejmując ważne resorty, oraz ze wspomnianych deklaracji T. Mazowieckiego w sprawie stosunku nowych władz polskich do Układu Warszawskiego. Zdaniem polskiej dyplomacji, niezależnie od dalszego utrzymywania się negatywnego stosunku władz rumuńskich do „Solidarności” i w ogóle krytyki kierunku przemian zachodzących wówczas w niektórych krajach Bloku Wschodniego, dojrzewał w Bukareszcie również pogląd o konieczności dostosowania się do nowej sytuacji, co Polacy ponownie oceniali jako rezultat stanowczości polskiej odpowiedzi na ,, inicjatywy” $R P K^{36}$ oraz niepodjęcia ich przez inne kraje socjalistyczne. Ceauşescu skupił się więc bardziej na ochronie i wzmocnieniu własnej władzy.

\footnotetext{
${ }^{34}$ Ibidem, Depesza ministra Olechowskiego do MSZ w Warszawie, 5.09.1989, syg. D I 3137/89, k. 6-6a; Notatka informacyjna na temat sytuacji wewnętrznej i polityki zagranicznej Rumunii w III kwartale 1989 r., wrzesień 1989, syg. R-2412-5-89, k. 31-32.

${ }^{35}$ Ibidem, Notatka informacyjna na temat sytuacji wewnętrznej i polityki zagranicznej Rumunii w III kwartale 1989 r..., k. 31 .

${ }^{36}$ Ibidem, Depesza ambasady PRL w Bukareszcie do MSZ w Warszawie, 12.09.1989, syg. D I 3210/89, k. 5-5a.
} 
Rzecz jasna, w tym okresie dyplomaci PRL w Bukareszcie znajdowali się w trudniej sytuacji. Utrudniano im normalne funkcjonowanie, blokując dostęp do informacji, nadal też dochodziło do szykan, a nawet ostrych interwencji wobec polskich turystów (byli wśród nich także handlarze-przemytnicy). Z Bukaresztu do Warszawy przesyłano coraz więcej informacji o pogarszającej się sytuacji gospodarczej Rumunii, narastających konfliktach społecznych i narodowościowych, powiększającej się izolacji SRR na arenie międzynarodowej. W świetle polskich obserwacji, w korpusie dyplomatycznym w Bukareszcie panowała opinia o odwróceniu ról w postaci prób wptywania [przez Rumunię] na rozwój sytuacji w Polsce, a więc zaprzeczania dotychczas tak silnie eksponowanej przez Rumunię tezy o niedopuszczalności mieszania się w sprawy wewnętrzne innych krajów $w^{37}$.

$\mathrm{W}$ trudnym położeniu, choć z diametralnie odmiennych przyczyn, znalazła się również placówka dyplomatyczna SRR w Warszawie, zmuszana teraz do częstszych interwencji z powodu - jak twierdziła - kampanii antyrumuńskiej w powiązanych z „Solidarnością” środkach masowego przekazu, czy kolejnych manifestacji przed jej siedzibą przeciwko polityce N. Ceauşescu ${ }^{38}$, która była oczywiście ,wdzięcznym” tematem dla antykomunistycznej opozycji. Z drugiej strony, w nowej sytuacji centrala w Bukareszcie sugerowała teraz, by mimo wszystko nawiązywać kontakty robocze również z „Solidarnością”, czyli generalnie z opozycją, która powinna być informowana o osiagnięciach narodu rumuńskiego pod przewodnictwem partii komunistycznej we wszystkich obszarach praktycznej $i$ duchowej działalności. Tłumaczenie dziennikarzom niedawnej akcji RPK i polskiej riposty miało iść w kierunku niewłaściwych interpretacji zamiarów Bukaresztu ${ }^{39}$. W październiku ze wspomnianych działań antyrumuńskich w Polsce można wskazać choćby zorganizowane na Uniwersytecie Warszawskim 28 października przez Polski Komitet Helsiński i Niezależne Zrzeszenie Studentów spotkanie z rumuńskimi dysydentami: Mihaiem Berindei i Adrianą Cornei na temat praw człowieka i sytuacji społeczno-politycznej w Rumunii ${ }^{40}$.

20 listopada ambasador Teşu, na polecenie swoich władz, złożył w polskim MSZ kolejny protest przeciwko demonstracjom przez ambasadą SRR i przeciwko zbyt jednostronnemu - jego zdaniem - ukazywaniu w środkach masowego przekazu obrazu rumuńskiej rzeczywistości. Oba państwa żyły już jednak w odmiennych realiach, dlatego strona polska ograniczyła się do stwierdzenia, iż podczas manifestacji nie zanotowano żadnych ekscesów, natomiast w warunkach wolności prasy nie można traktować każdej publikacji jako oficjalnego stanowiska polskiego rządu, który stara się utrzymywać dobre stosunki z Rumunią. Jak zauważyli Polacy, tym razem zwracała uwage już bardzo łagodna forma wypowiedzi Teşu, który wielokrotnie powolywat się na obowiqzujaca go dyscyplinę $w$ wykonywaniu poleceń centrali, dajac jednocześnie wyraźnie do zrozumienia, że nie w petni je aprobuje. Podkreślać miat swoje zrozumienie dla procesów zachodzqcych $w$ Polsce, w których naturalne miejsce zajmuje daleko idaca swoboda wypowiedzi i przejawiania stanowiska przez różne sity polityczne, funkcjonujace w kraju. Sam Teşu stwierdził, iż

${ }^{37}$ Ibidem, Notatka informacyjna $n[a]$ t[emat] sytuacji wewnętrznej i polityki zagranicznej Rumunii w III kwartale 1989 r...., k. 26-33.

${ }^{38}$ AMAE, RBRP, Depesza Ambasady SRR w Warszawie do MSZ w Bukareszcie, 8.10.1989, fond 1989/710, dos. 220/2, k. 63-64.

${ }^{39}$ Ibidem, Depesza MSZ w Bukareszcie do Ambasady SRR w Warszawie, 12.10.1989, k. 62.

${ }^{40}$ Ibidem, Depesza Ambasady SRR do MSZ w Bukareszcie, 31.10.1989, k. 68. 
w swych raportach do Bukaresztu stara się oddziaływać tonizujaco, zapobiegać dramatyzowaniu sytuacji $i$ wyjaśniać istote przemian w Polsce, których percepcja w Rumunii jest dość jednostronna, co w świetle jego raportów nie do końca odpowiadało rzeczywistości ${ }^{41}$.

Władze RPK nadal starały się podtrzymywać kontakty z PZPR, dla której nie miało to już żadnego znaczenia. Mimo to na odbywający się w dniach 20-24 listopada XIV zjazd RPK wyleciała z Polski kilkuosobowa delegacja, choć mniej znanych i raczej „,konserwatywnych" działaczy, na czele z członkiem Biura Politycznego Kazimierzem Cypryniakiem, co zapewne nie było przypadkowe. 23 listopada Cypryniak został przyjęty przez Ceauşescu, otrzymał wówczas kolejne zaproszenia do odwiedzenia Rumunii dla W. Jaruzelskiego i M. Rakowskiego ${ }^{42}$. W tym czasie zawężały się jednak kontakty Rumunii także z NRD, Czechosłowacją czy Bułgarią, których władze same zaczęły bać się o swoją przyszłość, w sytuacji gdy runęła już granica na murze berlińskim, ustąpił ze swojego stanowiska przywódca Bułgarii Todor Żiwkow, wybuchła ,aksamitna rewolucja” w Pradze czy demonstracje w Sofii. Trwała więc wschodnioeuropejska Jesień Ludów, ale trzymała się anachroniczna władza Ceauşescu, który przy aplauzie partyjnych klakierów przedłużył ją na listopadowym zjeździe RPK na kolejną kadencję. Żyjąc w złotej klatce, jeszcze 4 grudnia w Moskwie, przy okazji kolejnego szczytu Układu Warszawskiego, ponownie zaproponował Gorbaczowowi zorganizowanie spotkania liderów partii komunistycznych i robotniczych, co także i teraz spotkało się ze stanowczą odmową. Ceauşescu poczuł, że jest osamotniony ${ }^{43}$.

W końcu listopada swoją misję w Bukareszcie zakończył ambasador Woźniak, zastąpiony przez urzędującego już wcześniej w Bukareszcie Jerzego Bauera w niższej randze chargé d'affaires, co mogło świadczyć też o randze, jaką Warszawa przykładała wówczas do stosunków z państwem Ceauşescu. Po wybuchu walk ulicznych w Timişoarze (16 grudnia), które zapoczątkowały rumuńską rewolucję 1989 roku, doszło do kolejnej, tym razem ostrzejszej manifestacji przeciwko rządom Ceauşescu przed ambasadą SRR w Warszawie. Według relacji I. Teşu, po południu 20 grudnia ponad 300 osób, reprezentujacych radykalne $i$ ekstremistyczne organizacje i grupy, zapaliło na ogrodzeniu budynku świece, a przed bramą ustawiło ze świec krzyż. Dochodzić miało do chuligańskich aktów wandalizmu, wybijania szyb w oknach, rzucania farb na ściany budynku itp. Przed ambasadą odczytano szereg oświadczeń, w tym z żądaniem zerwania przez Polskę stosunków gospodarczych z Rumunią. Według Teşu, siły milicyjne były obecne, ale nie interweniowały ${ }^{44}$. Z kolei według ambasady polskiej w Bukareszcie, władze RPK rozsiewały pogłoski, że aktualne niepokoje w Siedmiogrodzie podsycane były przez kraje sqsiadujace i Polskę ${ }^{45}$, co było typowym zrzucaniem odpowiedzialności na siły zewnętrzne. 20 grudnia wieczorem przedstawiciele NRD, Bułgarii, Czechosłowacji i Polski zostali wezwani do mianowanego 2 lis-

\footnotetext{
${ }^{41}$ MSZ, D I, R, Notatka informacyjna z rozmowy z ambasadorem Rumunii, Ionem Teşu w dniu 20 bm., na jego prośbe, 21.11.1989, syg. R-2412-8-89, k. 17-18.

${ }^{42}$ AMAE, RBRP, Depesza MSZ w Bukareszcie do Ambasady SRR w Warszawie, 27.11.1989, fond 1989/710, dos. 220/2, k. 98 .

${ }^{43}$ A. Burakowski, Geniusz Karpat..., s. 342-343; Th. Kunze, Ceaşescu ..., s. 366-368.

${ }^{44}$ AMAE, RBRP, Depesza ambasady SRR $w$ Warszawie do MSZ w Bukareszcie, 20.12.1989, fond 1989/710, dos. 220/2, k. 101-103.

${ }^{45}$ AMSZ, D I, R, Depesza ambasady PRL w Bukareszcie do MSZ w Warszawie, 20.12.1989, syg. D I $0-4455 / 89$, k. 22-22a.
} 
topada szefem dyplomacji SRR ministra Stoiana, który wygłosił tyradę na temat zamachu na suwerenność i integralność SRR ze strony kół rewizjonistycznych, czyli Węgrów, oraz imperialistycznych, czyli Amerykanów, łącząc rozpoczętą w tym samym dniu interwencję zbrojną USA w Panamie z wydarzeniami w Rumunii. W międzynarodowym spisku, zawiązanym - według władz SRR - podczas spotkania Gorbaczowa i Busha na Malcie (2-3 grudnia) w celu nowego podziału wpływów na świecie, uczestniczyć miał też ZSRR, który szykuje się do interwencji, łacznie z interwencja zbrojnq, na co Rumunia stanowczo odpowie. Prosił o solidarność z Rumunami w ich walce o niepodległość i integralność. Miało dojść wówczas także do ostrej wymiany zdań między Stoianem a ambasadorem Bułgarii, gdy ten drugi stanowczo zaoponował przeciwko oskarżaniu ZSRR o plany inwazyjne. Niedługo potem przedstawiciel Kremla usłyszał podobne oświadczenie od samego N. Ceauşescu, z tą różnica, iż to inne kraje Układu Warszawskiego, a szczególnie Węgry ponoszą odpowiedzialność za zaplanowanie i zorganizowanie wydarzeń w Timişoarze. Miotający się w swojej bezsilności, coraz bardziej zirytowany lider RPK prosił, aby Gorbaczow wpłynął na te państwa w celu zmiany ich wrogiego stosunku do Rumunii ${ }^{46}$. Chcąc chronić swoją władzę, mógł się powoływać na zasadę nieingerencji, za którego orędownika chciał zawsze uchodzić, w tym na zasady uchwalone w lipcu na posiedzeniu przedstawicieli Układu Warszawskiego, które traktował instrumentalnie. Następnego dnia sprawa była już jednak nieaktualna. 23 grudnia, już po ucieczce Ceauşescu z gmachu KC RPK przed atakującym go tłumem, ambasada SRR w Warszawie (podobnie jak dyplomaci rumuńscy w wielu innych stolicach) o 180 stopni zmieniła swoje stanowisko, potępiając reżim Geniusza Karpat ${ }^{47}$.

\section{Problem Polaków na Bukowinie}

Odzwierciedleniem złej atmosfery na linii Bukareszt-Warszawa może być również, wywołana przez artykuł „Gazety Wyborczej” z 24 sierpnia 1989 roku na temat ciężkiego losu Polonii bukowińskiej, ostra reakcja dyplomacji rumuńskiej, oskarżającej stronę polską o oczernianie SRR $\mathrm{i}$ ingerowanie w jej wewnętrzne sprawy. Napięcie uległo zwiększeniu, gdy ambasada PRL, pomimo usłyszanych 2 września przez ambasadora Woźniaka pretensji na ten temat ze strony wiceministra Oancei, zdecydowała się na wysłanie na Bukowinę ,prywatnej” delegacji (2-3 września), która spotkała się z rodakami, przywożąc skromne podarunki i trochę żywności. Jednym z celów wizyty było zorientowanie się, czy polskim wsiom grozi opisana w „Gazecie Wyborczej” tzw. systematyzacja, czyli w zasadzie likwidacja $^{48}$. Ta pierwsza tego rodzaju wizyta od ponad trzydziestu lat kosztowała ambasadora

${ }^{46}$ Ibidem, Depesza ambasady PRL w Bukareszcie do MSZ w Warszawie, 21.12.1989, syg. D I 4456/89, k. 20-21; D I 4457/89, k. 19-19a; D I 4458/89, k. 18. Przedstawiciele ZSRR i NRD byli, podobnie jak J. Bauer, również tylko w randze charge d'affaires. O kontrowersjach wokół spraw rumuńskich podczas szczytu na Malcie i roli ZSRR w obaleniu Ceauşescu zob. np. A. Burakowski, Geniusz Karpat..., s. 341-344.

${ }^{47}$ AMAE, RBRP, Depesza ambasady SRR do MSZ w Bukareszcie, 23.12. 1989, fond 1989/710, dos. 220/2, k. 104.

${ }^{48}$ I.O., Polacy bez praw, chleba i domów, „Gazeta Wyborcza” nr 76 z 24.08.1989; AMAE, RPDP, Nota de audienta, 4 IX 1989, fond 1989/712, dos. 220, k. 107-109. Być może autorem tekstu w „GW” był Ireneusz Ochęduszko, w latach 1968-1973 ambasador PRL w SRR. 
Woźniaka wysłuchiwanie kolejnych pretensji w rumuńskim MSZ, które oczywiście nie powstrzymały dalszych polskich inicjatyw na odcinku polonijnym. Mimo wrogiej postawy władz rumuńskich, Polacy osiagnęli cel i do planowanych przekształceń wsi nie doszło. Ostatecznie Rumuni oświadczyli polskim dyplomatom, że obywatele rumuńscy narodowości polskiej cieszą się pełnym równouprawnieniem, a władze rumuńskie zastrzegają sobie wyłączność w decydowaniu o ich sprawach. W ten sposób ucięli wszelkie dalsze dyskusje i nie zgodzili się, aby przybyła 15 listopada do Rumunii delegacja polskich parlamentarzystów odwiedziła także Bukowinę ${ }^{49}$.

\section{Zakończenie}

Obserwując aktywność dyplomacji Nicolae Ceauşescu i jego osobiście w sprawach polskich w 1989 roku, można powiedzieć, że był to najbardziej obfity okres zainteresowania władz rumuńskich Polską w czasach rządów Geniusza Karpat. Dla władz RPK powód był oczywiście jeden, ale istotny, także dla przyszłości ich samych: rosnące od pierwszych tygodni nowego 1989 roku przekonanie - jak się okazało słuszne - o przyspieszającej w PRL drodze do upadku komunizmu. Ceauşescu próbował temu bezskutecznie zapobiegać, od prób koordynacji aktywności na tym odcinku całego Bloku Wschodniego po przebijające z dokumentów, choć niepotwierdzone, sugestie rozwiązań siłowych. W ówczesnych realiach przemian politycznych w ZSRR żadne $\mathrm{z}$ tych działań nie miały lub nie miałyby jednak szans na realizację, a przywódca Rumunii nie miał międzynarodowego autorytetu, aby stanąć na czele takiej antydemokratycznej krucjaty. Z kolei pytanie o zmianę poglądów człowieka, który wcześniej starał się utwierdzać świat w konieczności uszanowania suwerenności i woli każdego kraju do własnej drogi ustrojowej, potępiał inwazję na Czechosłowację w 1968 roku, uchodził na Zachodzie za enfant terrible w Bloku Wschodnim, a w 1989 roku chwalił opór panamskiego dyktatora Manuela Noriegi, krytkował ZSRR i PRL za prodemokratyczne reformy, przestrzegał przed USA i NATO, namawiał do zakwestionowania wyborów w Polsce, chcąc narzucać jej gotowe rozwiązania polityczne w omawianym okresie - można uznać za retoryczne. W 1989 roku głoszone wcześniej slogany oraz podejmowane działania na odcinku polskim miały na celu jedynie uratować jego własny świat przez upadkiem.

\section{Wykaz źródel i opracowań}

Archiwalia:

Archiwum Ministerstwa Spraw Zagranicznych w Warszawie:

- Departament I, Rumunia

Arhiva Ministerului Afacerilor Exter-ne în Bucureşti:

- Probleme interne din Polonia. Situația socio-politică

- Relații bilaterale româno-polone (politico-diplomatice)

- Relații politico-diplomatice cu România, Polonia

${ }^{49}$ Szerzej zob. K. Nowak, Dyplomacja polska a Polacy w Rumunii w okresie politycznych przełomów (czerwiec-grudzień 1989 roku), [w:] Historia i dzień dzisiejszy relacji polsko-rumuńskich/Istoria şi prezentul relațiilor polono-române, red. K. Stempel-Gancarczyk, E. Wieruszewska-Calistru, Suceava 2017, s. $229-241$. 
Prasa:

„Gazeta Wyborcza” 1989

Opracowania:

Betea L., Mihai F.-R., Țiu I., 21 august 1968. Apoteoza lui Ceauşescu, wyd. II, București 2018. Burakowski A., Geniusz Karpat. Dyktatura Nicolae Ceauşescu 1965-1989, Warszawa 2008.

Kunze Th., Ceausescu. Piekło na ziemi, Warszawa 2016.

Nowak K., Dyplomacja polska a Polacy w Rumunii wokresie politycznych przełomów (czerwiec-grudzień 1989 roku), [w:] Historia i dzień dzisiejszy relacji polsko-rumuńskich/ Istoria şi prezentul relațiilor polono-române, red. K. Stempel-Gancarczyk, E. Wieruszewska-Calistru, Suceava 2017, s. 229-241.

Rychlík J., Politické změny ve Východni Evropě před 17. listopadem a jejich ohlas v Československu, „Česko-slovenská historická ročenka” 2009, s. 113-156.

Strony internetowe [ostatni dostęp 5.06.2020]:

Did Nicolae Ceauşescu Call for Military Intervention Against Poland in August 1989?, CWIHP, Wilson Center, e-Dossier No 60, https://www.wilsoncenter.org/publication/did-nicolae-ceausescucall-for-military-intervention-against-poland-august-1989.

Continuing Debate: Ceauşescu's Appeal for Joint Warsaw Pact Action on 19 August 1989, CWIHP, Wilson Center, e-Dossier No 61, https:/www.wilsoncenter.org/publication/continuing-debateceausescus-appeal-for-joint-warsaw-pact-action-19-august-1989.

Resolution of the CPSU CC Politburo No. 132, Regarding the Appeal of Cde. Ceauşescu, August 21, 1989, History and Public Policy Program Digital Archive, RGANI, F. 3, Op. 103, D. 180, L. 63, and RGANI, F. 3, Op. 103, D. 181, Ll. 140-141. Translated for CWIHP by Mark Kramer, http:// digitalarchive.wilsoncenter.org/document/121621.

Soviet Ambassador to Romania E. M. Tyazhel'nikov, Record of a Conversation with N. Ceaussescu and Message for Gorbachev, August 19, 1989, History and Public Policy Program Digital Archive, Rossiiskii Gosudarstvennyi Arkhiv Noveishei Istorii (RGANI), Fond 5, Opis' 102, Delo 80, Listy 107-110. Obtained and translated for Cold War International History Project by Mark Kramer, http://digitalarchive.wilsoncenter.org/document/121614.

Transcript of Meeting of the Executive Politburo of the Central Committee of the RomanianCommunist Party, August 21, 1989, History and Public Policy Program Digital Archive, Stenograma şedinței Comitetului Politic Executiv al C.C. al P.C.R. din ziua de 21 august 1989, Arhiva Nationale Romanesti, Fond CC al PCR, Sectia Cancelarie, Dosar Nr. 57/1989, f. 1-6. Translated for CWIHP by Larry Watts, http://digitalarchive.wilsoncenter.org/document/121611.

Krzysztof Nowak, dr hab., prof. UŚ, pracownik naukowy Instytutu Historii Uniwersytetu Śląskiego w Katowicach, w latach 2012-2019 kierownik Zakładu Historii Najnowszej po 1945, od roku 2012 członek Komisji Środkowoeuropejskiej PAU, od 2013 członek Rady Programowej Forum Polsko-Czeskiego przy MSZ, od 2015 członek Komisji Bałkanistyki przy Oddziale PAN w Poznaniu, od 2018 członek Komisji Historycznej PAN w Katowicach. Zainteresowania badawcze: historia Europy Środkowo-Wschodniej, historia Pograniczy, stosunki narodowościowe, stosunki polsko-czesko-słowackie, stosunki polsko-rumuńskie w XX w., historia Polonii, historia Śląska Cieszyńskiego, historia Bukowiny, historia turystyki. Autor m.in. pracy: Mniejszość polska w Czechosłowacji 1945-1989. Między nacjonalizmem a ideq internacjonalizmu, Cieszyn 2012.

krzysztof.nowak@us.edu.pl 